\title{
Production of an extensive sunflower protein hydrolysate by sequential hydrolysis with endo- and exo-proteases
}

\author{
By Alvaro Villanueva, Javier Vioque, Raúl Sánchez-Vioque, Alfonso Clemente, Juan Bautista ${ }^{1}$ \\ and Francisco Millán * \\ Instituto de la Grasa. Avda. Padre García Tejero, 4. 41012 - Sevilla, Spain. \\ 1 Department of Biochemistry, Bromatology and Toxicology. University of Seville 41012-Seville, Spain.
}

\section{RESUMEN}

Producción de un hidrolizado proteico extenso de girasol mediante hidrólisis secuencial con endo- y exo-proteasas.

Se ha obtenido un aislado proteico de alta calidad a partir de harina desengrasada de girasol, mediante extracción alcalina y precipitación isoeléctrica. Se incrementó el contenido proteico desde un $31.2 \%$ en la harina desengrasada hasta un $97 \%$ en el aislado proteico. Los porcentajes de fibra, azúcares solubles, polifenoles y lípidos residuales se redujeron en más del $90 \%$ en el aislado proteico respecto a la harina desengrasada. Se usó el aislado proteico como material de partida para la producción de un hidrolizado enzimático proteico extenso. La hidrólisis se realizó en un reactor usando secuencialmente una endo-proteasa (Alcalasa) y una exo-proteasa (Flavorzima). El hidrolizado proteico, con un grado de hidrólisis del $50.7 \%$, era blanco y no presentaba amargor.

PALABRAS-CLAVE: Aislado proteico - Alcalasa - Flavorzima Girasol - Hidrolizado proteico.

\section{SUMMARY}

Production of an extensive sunflower protein hydrolysate by sequential hydrolysis with endo- and exo-proteases.

A high quality protein isolate has been obtained from defatted sunflower meal by alkaline extraction and isoelectric precipitation. Protein content was increased from $31.2 \%$ in the defatted flour to $97 \%$ in the protein isolate. The percentages of fiber, soluble sugars, polyphenols and residual lipids in the protein isolate were reduced to more than $90 \%$ with respect to the defatted meal. The protein isolate was used as starting material for the generation of an extensive enzymatic protein hydrolysate. The hydrolysis was carried out in a pH stat using sequentially an endo-protease (Alcalase) and an exo-protease (Flavourzyme). The protein hydrolysate, with a degree of hydrolysis of $50.7 \%$, was white and non bitter.

KEY-WORDS: Alcalase - Flavourzyme - Protein hydrolysate Protein isolate - Sunflower.

\section{INTRODUCTION}

The increasing growth of population and the reduction in food resources in the third world and the excessive intake of animal proteins which are unhealthy for the ingestion of the associated saturated fats, have led to interest in the search for new sources of proteins from non-conventional raw materials.

Sunflower is one of the most important oilseed crops cultivated in the world, ranking fourth with respect to oil production. Major producer countries are Rusia, Argentina, France, U.S.A., China and Spain (Lühs et al., 1994). Defatted meal is the main by-product after oil extraction. This meal, containing about $40-45 \%$ protein, may constitute an optimal source of proteins for humans. To make use of these proteins, sunflower meal requires processing to lower the contents in undesirable components such as soluble sugars, polyphenols and lipids that may reduce the chemical and nutritive value of the proteins. Also, fiber, one of the main components of the defatted meal, should be eliminated to enrich the final product in protein.

Processing of the starting material is also desirable to improve functional characteristics of the product. Sunflower proteins, during the industrial oil extraction, are partially denatured, thus reducing their solubility (Cheftel et al., 1985). To increase solubility, proteins may be hydrolyzed enabling their use as food additives in the fortification of liquid foods. Also, protein hydrolysates are absorbed faster than the corresponding proteins (Matthews, 1977) and have lower osmotic pressure than free amino acids (Adibi, 1989).

Sunflower protein hydrolysates have been obtained in the past using proteases such as kerase (Parrado et al., 1991, Parrado et al., 1993). In these cases the substrate for hydrolysis is a protein concentrate that still contain high amounts of non-desirable components such as fiber. The final hydrolysate obtained had a dark color and it was slightly bitter with a $18.8 \%$ degree of hydrolysis. The objective of the present research was the production of a high quality sunflower protein isolate and its use for the generation of an extensive sunflower protein hydrolysate using sequentially an endo-protease (Alcalase) and an exo-protease (Flavourzyme). The combined action of these proteases with different catalytic activities will produce an extensive hydrolysate, of high quality, that can be used directly in the 
supplementation of liquid foods, thus widening the field of application of sunflower proteins.

\section{MATERIALS AND METHODS}

\subsection{Raw material}

Defatted sunflower meal, provided by Koipesol (Seville, Spain) and obtained by the prepress solvent extraction system, was used as protein source.

\subsection{Proteases}

The enzymatic complexes used were Alcalase $2.4 \mathrm{~L}$ and Flavourzyme 1000 MG (Novo Nordisk, Bagsvaerd, Denmark). Alcalase $2.4 \mathrm{~L}$ is an endoprotease from Bacillus licheniformis, with Subtilisin Carlsberg as the major enzymic component, having a specific activity of 2.4 Anson Unit (AU) per gram. One $A U$ is the amount of enzyme which digests haemoglobin at an initial rate that produces an amount of trichloroacetic acid-soluble product which gives the same colour with the Folin reagent as one miliequivalent of tyrosine released per minute. Flavourzyme $1000 \mathrm{MG}$ is an exoprotease and endoprotease complex with an activity of 1.0 Leucine aminopeptidase unit (LAPU)/g. One LAPU is the amount of enzyme which hydrolyzes $1 \mu$ mole of leucine-p-nitroanilide per minute.

\subsection{Determination of moisture, ash, nitrogen, and lipids}

They were determined according to $A O A C$ approved methods (AOAC, 1990).

\subsection{Total fiber determination}

Total fiber was determined according to an enzymaticgravimetric method (Lee et al., 1992). Samples (1 g) were dispersed in $40 \mathrm{ml}$ of $50 \mathrm{mM}$ Mes, $50 \mathrm{mM}$ Tris, $\mathrm{pH} 8.2$, and successively digested with $50 \mu \mathrm{l}$ of heat stable $\alpha$-amylase solution $\left(15 \mathrm{~min}\right.$ at $95^{\circ} \mathrm{C}$ ) (Amersham Pharmacia) $100 \mu \mathrm{l}$ of a $50 \mu \mathrm{g} / \mu \mathrm{l}$ protease solution (30 min at $\left.60{ }^{\circ} \mathrm{C}\right)$ (Sigma), and $300 \mu \mathrm{l}$ of amyloglucosidase solution (30 min at $60{ }^{\circ} \mathrm{C}$ ) (Sigma). After digestion, the samples were filtered through 40-60 $\mu \mathrm{m}$ pore size filters and the insoluble residue was dried, weighed, and ash and protein contents were measured. Percentage of total fiber was calculated using the following formula:

Total fiber $(\%)=[$ Insoluble residue $(\mathrm{g})$ - protein $(\mathrm{g})$ ash $(\mathrm{g}) /$ sample $(\mathrm{g})] \times 100$

\subsection{Soluble sugars determination}

Five grams of material were extracted with $200 \mathrm{ml}$ of $95 \%$ ethanol, stirring for $2 \mathrm{~h}$ at room temperature. After centrifugation at $4000 \times \mathrm{g}$ for $15 \mathrm{~min}$, the supernatant was filtered through $n .^{\circ} 1$ Whatman paper. Soluble sugars were estimated colorimetrically in this supernatant by the phenol-sulphuric acid method using a standard curve of glucose (Dubois et al., 1956).

\subsection{Polyphenols analysis}

Five grams of material were extracted with $200 \mathrm{ml}$ of $80 \%$ ethanol for $8 \mathrm{~h}$ in a Soxhlet and the ethanol volume was reduced to $25 \mathrm{ml}$ under vacuum at $40^{\circ} \mathrm{C}$. Samples were filtered through $n .^{\circ} 1$ Whatman paper and aliquots were used for measuring absorbance at $324 \mathrm{~nm}$ in a spectrophotometer (Beckman DU 640, Fullerton, CA, USA). Amounts of phenolic compounds were estimated as chlorogenic acid equivalents (Moores et al., 1948).

\subsection{Preparation of protein isolate}

Protein concentrate was obtained by the sedimentation/ flotation method (Parrado et al., 1991). Protein isolate was obtained by dispersing protein concentrate in $0.25 \%(\mathrm{w} / \mathrm{v}) \mathrm{Na}_{2} \mathrm{SO}_{3}, \mathrm{pH} 10.5$ at a ratio $1: 10$ (w:v) and extraction by shaking for $1 \mathrm{~h}$ at room temperature. After centrifugation at $8000 \mathrm{xg}$ for $15 \mathrm{~min}$, two additional extractions of the protein concentrate were carried out with half of the volume of alkaline solution. Supernatants were pooled and the $\mathrm{pH}$ adjusted with $\mathrm{HCl} 6 \mathrm{~N}$ to 4.3 that corresponds to the isoelectric point of sunflower proteins. After centrifugation at $8000 \times \mathrm{g}$ for $15 \mathrm{~min}$, the precipitate was washed with water at $\mathrm{pH} 4.3$, frozen at $-20^{\circ} \mathrm{C}$ and lyophilized for further uses.

\subsection{Enzymatic hydrolysis}

The protein isolate was hydrolyzed batchwise with Alcalase 2.4 L and Flavourzyme 1000 MG by individual or sequential treatment. Individual hydrolysis were done for $3 \mathrm{~h}$ while sequential treatment was carried out as follows: an initial hydrolysis $(1 \mathrm{~h})$ using Alcalase $2.4 \mathrm{~L}$ alone as endo-protease, and a second one ( $2 \mathrm{~h}$ ) by adding Flavourzyme $1000 \mathrm{MG}$ as exo-protease. The hydrolysis was carried out using the following parameters: A) Alcalase hydrolysis, substrate concentration $(S)=5 \%$; enzyme-substrate ratio $(E / S)=0.4 \mathrm{AU} / \mathrm{g}$ protein; temperature $(\mathrm{T})=50^{\circ} \mathrm{C}$; $\mathrm{pH} 8.0$; B) Flavourzyme hydrolysis, $\mathrm{S}=5 \%$; $E / S=100$ 
LAPU/g protein, $\mathrm{T}=50^{\circ} \mathrm{C}, \mathrm{pH}$ 7.0. The hydrolysis was conducted in a $1000 \mathrm{~mL}$ reaction vessel, equipped with a stirrer, thermometer and $\mathrm{pH}$ electrode. Hydrolysis was stopped by heat treatment at $85^{\circ} \mathrm{C}$ for $10 \mathrm{~min}$.

\subsection{Degree of Hydrolysis}

The degree of hydrolysis, defined as the percentage of peptide bonds cleaved, was measured by determination of free amino groups by reaction with trinitrobenzenesulphonic acid (TNBS) according to Adler-Nissen (1979). Total number of amino groups were determined in a sample 100 $\%$ hydrolyzed by acid hydrolysis at $110^{\circ} \mathrm{C}$ for $24 \mathrm{~h}(10 \mathrm{mg}$ sample in $4 \mathrm{ml} 6 \mathrm{~N} \mathrm{HCl}$ ).

\subsection{Amino acid analysis}

Samples $(10 \mathrm{mg}$ ) were hydrolyzed with $4 \mathrm{ml}$ of $6 \mathrm{~N}$ $\mathrm{HCl}$. The solutions were sealed in tubes under nitrogen and incubated in an oven at $110^{\circ} \mathrm{C}$ for $24 \mathrm{~h}$. Amino acids composition was determined in the acid hydrolysis, after derivatization with diethyl ethoxymethylenemalonate, by high performance liquid cromatography with $D, L-\alpha$-aminobutyric acid as internal standard, according to the method of Alaiz et al., (1992). The HPLC system consisted of a Model 600E multi-system with a 484 UV-Vis detector (Waters, Milford. MA, USA). Separations were attained with a $300 \times 3.9 \mathrm{~mm}$ I.D. reversed phase column (Novapack $\mathrm{C}_{18}, 4 \mu$, Waters) using a binary gradient system. The solvents used were (A) $25 \mathrm{mM}$ sodium acetate containing $0.02 \%$ sodium azide $(\mathrm{pH} 6.0)$ and $(\mathrm{B})$ acetonitrile. The solvent was delivered to the column at a flow rate of $0.9 \mathrm{ml} / \mathrm{min}$ as follows: time $0.0-3.0 \mathrm{~min}$, linear gradient from $A: B(91: 9)$ to $A: B(86: 14) ; 3.0-13.0 \mathrm{~min}$, elution with $A: B(86: 14) ; 13.0-30.0$ min, linear gradient from $A: B(86: 14)$ to $A: B(69: 31) ; 30.0-35.0$ min, elution with $A: B(69: 31)$. The column was maintained at $18^{\circ} \mathrm{C}$ by a temperature controller.

\section{RESULTS AND DISCUSSION}

\subsection{Preparation of protein isolates}

Plant protein isolates constitute an optimal material for the supplementation of new types of foods and are a good substrate for the generation of enzymatic protein hydrolysates. Protein isolates are enriched in total proteins and have low amounts of compounds such as soluble sugars, lipids, phenols or fiber. Soluble sugars and lipids are undesirable components because they may react with proteins by Maillard reaction generating a deficit in essential amino acids such as lysine, tryptophan and methionine (Waller et al., 1983). Polyphenols are easily oxidized to quinones that may be transformed into brown polymerics substances affecting the external appearance of the product (Cater et al.,
1972). Fiber is undesirable in the production of protein because proteases absorb unspecifically to the fiber lowering their activity and increasing the costs of the process (Bonino et al., 1977).

For the generation of the protein concentrate, defatted sunflower meal was fractionated by a sedimentation/flotation method as described earlier (Parrado et al., 1991). This procedure starts by mixing the material with water $(\mathrm{pH} 7)$ generating an homogeneous dispersion. The mixture of defatted flour in water is settled down by sedimentation to obtain three fractions: an upper floating or lignocellulosic fraction made of fiber, a lower or protein fraction, settled at the bottom and made of solid particles enriched in proteins, and in between these fractions a soluble one containing soluble proteins, sugars and phenols. The protein fraction is recovered and subjected again to sedimentation/ flotation but using ethanol $10 \%$ in water as liquid phase. With this step most of remaining polyphenols are extracted. The final protein concentrate obtained has reduced contents of soluble sugars, lipids and polyphenols to more than $90 \%$ with respect to the original meal. Conversely, the protein content is increased from $31.18 \%$ in the defatted meal to 48.40 $\%$ in the protein concentrate. Nevertheless, the fiber contents are still high representing $17.95 \%$ of the total (Table I). To eliminate this fiber, the next step is the generation of a protein isolate by basic extraction and acid precipitation of proteins. For the alkaline extraction, a solution containing sodium sulfite was used. This compound is an useful antioxidant that will prevent the oxidation of remaining polyphenols and hence the browning of the product (Gheyasuddin et al., 1970). The extracted proteins are precipitated at the isoelectric point of sunflower proteins $(\mathrm{pH}$ 4.3) by acidification with $\mathrm{HCl}$. The pellet obtained represent the protein isolate that is stored and dried until used in the hydrolysis process. The protein percentages in the isolate has been increased, with respect to the defatted meal, to contents above $95 \%$ and amounts of total fiber, lipids, phenols and soluble sugars reduced by more than $90 \%$ (Table I).

The recoveries of proteins during the generation of the protein isolate are shown in Figure 1. In the final protein isolate $34.2 \%$ of the proteins originally present in the defatted flour is recovered. Proteins remaining in the solid residues (lignocellulosic fraction and residue after alkaline extraction) representing $48.1 \%$ of the proteins in the original meal, could be useful, for example, for animal feeding. Also, proteins remaining in soluble fractions could be recovered by ultrafiltration. These proteins, because of their water solubility, may be a suitable material for the supplementation of food for parenteral diets or for the enrichment of liquid beverages. The described process did not result in changes in the amino 
acid composition of protein extracted (Table II). Only lysine contents are lower in the protein isolate than in the original flour, probably because the interactions of sunflower proteins with oxidized lipids or soluble sugars has produced a partial degradation of this amino acid. In relation with FAO requirements, the protein isolate is limiting only in lysine, as the original defatted meal.

Table I

Chemical composition of defatted sunflower meal (DSM), protein concentrate (PC) and protein isolate (PI)

\begin{tabular}{lccc}
\hline & DSM & PC & PI \\
\hline Dry Matter & $90.32 \pm 0.50$ & $91.11 \pm 0.50$ & $95.87 \pm 0.50$ \\
Moisture & $9.68 \pm 0.50$ & $8.89 \pm 0.60$ & $4.13 \pm 0.60$ \\
Ash & $4.86 \pm 0.20$ & $5.54 \pm 0.30$ & $1.01 \pm 0.20$ \\
Crude protein $(\mathrm{N} \times 6.25)$ & $31.18 \pm 1.60$ & $48.40 \pm 2.10$ & $97.03 \pm 2.00$ \\
Lipids & $6.05 \pm 0.60$ & $0.63 \pm 0.50$ & $0.29 \pm 0.05$ \\
Fiber & $25.09 \pm 1.30$ & $17.95 \pm 0.80$ & $0.98 \pm 0.20$ \\
Soluble sugars & $3.79 \pm 0.25$ & $0.23 \pm 0.08$ & $0.20 \pm 0.06$ \\
Polyphenols & $2.14 \pm 0.60$ & $0.21 \pm 0.05$ & $0.20 \pm 0.07$ \\
Others & $17.21 \pm 0.10$ & $18.15 \pm 0.20$ & $0.29 \pm 0.06$ \\
\hline
\end{tabular}

Results are expressed as percent of dry matter of the mean $\pm S D$ of three determinations.

Table II

Amino acid composition (grams per $100 \mathrm{~g}$ of protein) of defatted sunflower meal (DSM), protein concentrate (PC) and protein isolate (PI)

\begin{tabular}{lcccc}
\hline & DSM & PC & PI & FAO $^{\mathrm{a}}$ \\
\hline Asp + Asn & 9.6 & 9.5 & 10.7 & \\
Glu + Gin & 21.1 & 20.3 & 22.1 & \\
Ser & 5.5 & 5.3 & 5.1 & \\
His & 3.0 & 2.8 & 2.9 & 1.9 \\
Gly & 6.4 & 6.0 & 4.5 & \\
Thr & 4.8 & 4.3 & 3.6 & 3.4 \\
Arg & 11.2 & 10.8 & 11.6 & \\
Ala & 4.1 & 3.9 & 3.7 & \\
Pro & 0.9 & 4.5 & 5.1 & \\
Tyr & 3.1 & 3.1 & 3.2 & \\
Val & 5.0 & 4.6 & 4.1 & 3.5 \\
Met & 2.3 & 2.7 & 2.9 & $2.5^{\mathrm{b}}$ \\
Cys & 2.3 & 2.3 & 2.0 & \\
Ile & 4.6 & 4.2 & 3.9 & 2.8 \\
Leu & 7.1 & 7.1 & 6.8 & 6.6 \\
Phe & 4.8 & 4.7 & 5.2 & $6.3^{\mathrm{c}}$ \\
Lys & 4.2 & 3.9 & 2.6 & 5.8 \\
\hline
\end{tabular}

a FAONHO protein quality evaluation 1985. (FAOMHO/ONU. Energy and protein requeriments. Reports of a joint meeting. WHO, Geneva, 1985, Technical report series N. ${ }^{\circ} 724$ ).

b Met + Cys

c Phe + Tyr

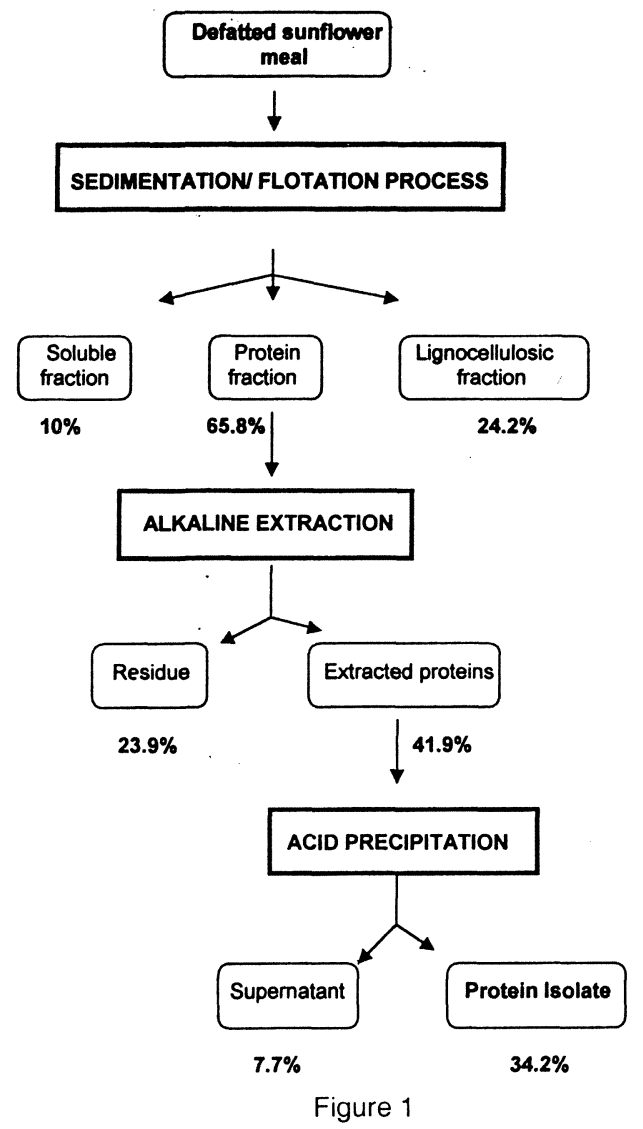

Preparation of Sunflower Protein Isolate. Protein recovery in each fraction is shown as \% with respect to the protein content $(100 \%)$ of the original meal

\subsection{Generation of extensive protein hydrolysates}

For the production of the hydrolysates we have used two proteases, Alcalase and Flavourzyme, with different catalytic activites. Alcalase is a protease with endoprotease activity that has been widely used for the generation of protein hydrolysates (AdlerNissen, 1986). Flavourzyme is an exoprotease used for debittering and generation of extensive hydrolysates.

The protein hydrolysis is carried out in a $\mathrm{pH}$-stat by using sequentially the above proteases. The protein digestion is started with Alcalase. With this unspecific endoprotease, after 60 minutes, a protein hydrolysate with a $31.2 \%$ degree of hydrolysis it is obtained (Figure 2). With the predigestion with Alcalase an increase in the number of $\mathrm{N}$-terminal sites for the exoprotease activity of Flavourzyme is achieved. The predigestion with Alcalase should reduce costs since less amount of Flavourzyme is needed to obtain the same degree of hydrolysis. With this sequential hydrolysis an extensive hydrolysate with a higher degree of hydrolysis than using only Alcalase or Flavourzyme during the same time is obtained (Figure 2). Thus, with Alcalase a $34.7 \%$ hydrolysis, with Flavourzyme a $42.2 \%$ hydrolysis and combining both proteases a $54.3 \%$ hydrolysis is reached after three hours of reaction. 
This value represent $22.3 \%$ more hydrolysis than with Flavourzyme alone and $36 \%$ more than with Alcalase. The kinetic of hydrolysis with Alcalase is very fast in the initial minutes reaching a steady state after $30 \mathrm{~min}$. In this sense, the time of incubation with Alcalase could be reduced to $30 \mathrm{~min}$, to improve the efficiency of the process. On the other hand, Flavourzyme shows a kinetic of hydrolysis with a smaller slope, but a constant increment of the hydrolysis even after 3 hours incubation.

-A Alcalase - *-Flavourzyme -Alcalase + Flavourzyme

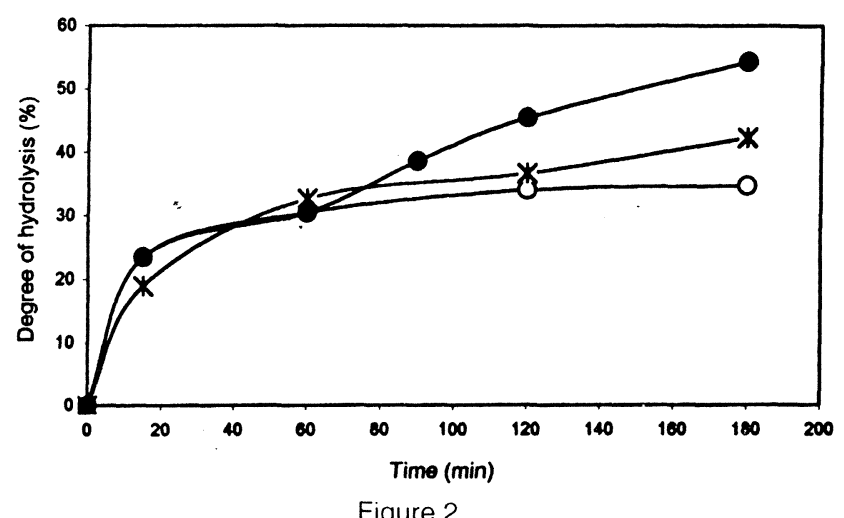

Enzymatic Hydrolisis of Sunflower Protein Isolate with Alcalase, Flavourzyme and Alcalase + Flavourzyme

A problem in the generation of protein hydrolysates is the production of bitter peptides. Bitterness seems to be caused by the exposure of hydrophobic residues as a consequence of the protein hydrolysis (Matthews, 1977). This problem has been observed in sunflower protein hydrolysates obtained with kerase (Parrado et al., 1991). It has been reported that free amino acids are less bitter than the corresponding peptides and that the bitterness is highest when the hydrophobic amino acids are nonterminal (Adler-Nissen, 1986). These factors suggest the use of an exoprotease to reduce bitterness of hydrolysates. In this sense, the final hydrolysate obtained by using sequentially Alcalase and Flavourzyme, when tested in a panel test, gave complete absence of bitterness.

In conclusion, combining two commercial proteases with different catalytic activities and using as starting material a high quality protein isolate we have generated an extensive non bitter hydrolysate of white color that can be used directly, for example, in the fortification of liquid foods or high energetic beverages, thus widening the field of application of sunflower proteins.

\section{ACKNOWLEDGMENTS}

This work was supported by CICYT Grant AL I 98-0766.

\section{REFERENCES}

Adibi, S.A. (1989).- «Glycyl dipeptides: new substrates for protein nutrition".-J. Lab. Clin. Med. 113, 665-673.

Adler-Nissen, J. (1979). - «Determination of the degree of hydrolysis of food protein hydrolysates by trinitrobenzenesulfonic acid».-J. Agric. Food Chem. 27, 1256-1262.

Adler-Nissen, J. (1986).—«Enzymic hydrolysis of food proteins".-Elsevier, London.

Alaiz, M., Navarro, J.L., Girón, J., and Vioque, E. (1992)."Amino acid analysis by high-performance liquid chromatography after derivatization with diethylethoxymethylenemalonate».-J. Chromatography 591, 181-186.

AOAC (1990).—- -Official Methods of Analysis". - $15^{\text {th }}$ ed. Association of Official Analytical Chemists, Arlington, U.S.A.

Bonino, M.F., Sceglio, O., and Frutos, E. (1974).-— «The value of sunflower seed meal for laying hens".-Proc. XV World's Poult. Cong. and Expos. 595-597.

Cater, C.M., Gheyasuddin, S., and Mattil, K.F. (1972)."The effect of chlorogenic, quinic and caffeic acids on the solubility and color of protein isolates, especially from sunflower seed".-Cereal Chem. 49, 508-514.

Cheftel, J.C., Cuq, J.-L., and Lorient, D. (1985).«Proteines alimentaires: Biochemie propietés functionelle. Valeur nutritionelle. Modificationes chimiques".-Techniques et Documentation Lavosier, Paris.

Dubois, M., Gilles, K.A., Hamilton, J. K., Rebers, P.A., and Smith, F. (1956). - "Colorimetric method for determination of sugars and related substances".-Anal. Chem. 28 350-356.

Gheyasuddin, S., Cater, C.M. and Mattil, K.F. (1970).«Preparation of a colorless sunflower protein isolate".-Food Technol. 24, 242-243.

Lee, S.C., Prosky, L., De Vries, J. W. (1992).«Determination of total, soluble and insoluble dietary fiber in foods-enzymatic-gravimetric method, MES-Tris buffer".-Journal of AOAC International 75, 395416.

Lühs, W., and Friedt, W. (1994).- «The major oil crops in Designer Oil Crops. Breeding, Processing and Biotechnology" Murphy, D.J., VCH, Weinheim (Eds.).- Germany, (1994).

Matthews, M. P. (1977)._- «Protein absorption-then and now".-Gastroenterology 73, 1267-1279.

Moores, R.G., Mc Dermott, D.L., and Wood, T.R. (1948)."Determination of chlorogenic acid in coffee».-Anal. Chem. 20, 620-624.

Parrado, J., Bautista, J., and Machado, A. (1991).«Production of soluble enzymatic protein hydrolysate from industrially defatted undehulled sunflower meal».-J. Agric. Food Chem. 39, 447-450.

Parrado, J., Millán, F., Hernández-Pinzón, I., Bautista, J., and Machado, A. (1993).- - "Characterization of enzymatic sunflower protein hydrolysates".-J. Agric. Food Chem. 41, 1821-1825.

Waller, G., and Feathe, M. (1983).- «The Maillard reactions in foods and nutrition".-Am. Chem. Soc. Washington, D.C. 